Brit J. industr. Med., 1960, 17, 36.

\title{
DRUG TREATMENT OF EXPERIMENTAL SILICOSIS
}

\author{
BY
}

DINAH M. JAMES*, T. G. MORRIS, and J. MARKS $\dagger$

From the Department of Pharmacology, Welsh National School of Medicine, the Pneumoconiosis Research Unit, Cardiff, and the Central Tuberculosis Laboratory, Cardiff

(RECEIVED FOR PUBLICATION FEBRUARY 12, 1959)

It has already been shown that tissue cultures of phagocytic cells may be protected against the toxic effect of silica dust by a number of organic bases and aluminium complexes. These compounds have now been used to treat mice after the administration of silica dust intravenously. Protective activity was measured by capacity to inhibit or retard the development of silicotic nodules in the livers of the experimental animals. Drugs active in this respect were an aluminiumdextran complex, phenazine B749, methylene blue, and compound 46-107. Compound 46-107 is related chemically to compound $48-80$, the subject of a previous study of protective action, but lacks the latter drug's disruptive effect on mast cells.

The nature of the injury suffered by cells which ingest silica dust is not known. It is possible that the dust dissolves to give a toxic form of silicic acid but recent observations (e.g., Englebrecht, Yoganathan, King, and Nagelschmidt, 1958) suggest that the biological activity of silica dust is a property of its surface, which presumably binds or distorts an important cell constituent.

Although there is experimental evidence that aluminium can protect animals against the effects of silica (Dworski, 1955), the value of aluminium in the prevention and treatment of silicosis in man is debatable (Kennedy, 1956), and it is uncertain whether the metal in the particulate form in which it is used can reach silica which has already entered lung tissue.

Previous observations on the interaction of methylene blue with silicic acid (James and Marks, 1956) suggested that soluble basic substances might be found with the capacity to neutralize the toxicity of silica dust. Subsequently an organic base, compound $48-80$, was found to inhibit the development of silicosis in mice given silica dust intravenously (Marks, James, and Morris, 1958). The main pharmacological activity of compound $48-80$, i.e., disruption of mast cells and histamine release, would appear to preclude any practical advantage that might be gained from its action on silica. A more recent examination of related compounds,

*Present address: Department of Pharmacology, University College, Ibadan, Nigeria.

†Now at the Tuberculosis Reference Laboratory, Public Health Laboratory Service. however, has shown that phagocytes may be protected in vitro against silica dust by drugs which do not show the mast cell effect (Marks, 1959). Several other substances were examined for protective activity in the same investigation.

The present communication describes the treatment of mice, previously injected intravenously with silica dust, with a variety of drugs, which were selected chiefly on the basis of their ability to protect phagocytes in vitro.

\section{Methods}

Administration of Silica and Drugs.- Tridymite dust was given intravenously to male albino mice weighing about $20 \mathrm{~g}$. in the manner described in our previous communication (Marks, et al., 1958). In experiments 1 to 4 , sample 4485 (Dvs $=1 \cdot 4 \mu$ ) was used in a single dose of $3.5 \mathrm{mg}$. In experiment 5 , sample $5145(\mathrm{Dvs}=0.7 \mu)$ was used in a dose of $5 \mathrm{mg}$. The dusts were provided by the Safety in Mines Research Establishment, Sheffield.

Except where otherwise stated, the drug schedules listed below all concern mice which had been given silica and received treatment by the intraperitoneal route beginning a few hours after the silica injection.

Compound 46-107.- This drug was prepared in two batches, $(a)$ and $(b)$, by the Wellcome Research Laboratories, New York; its formula is as follows (Marks, 1959):

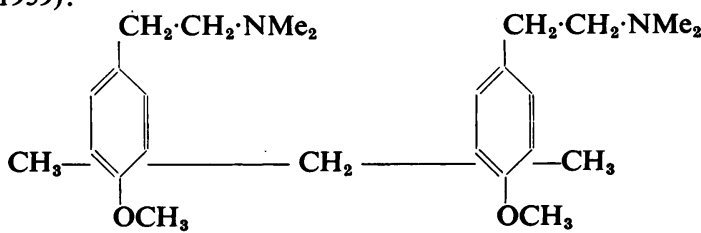


One dose was given daily, six days a week, using a fresh solution for each. The dose given initially was increased daily during the first week to reach the "normal dose" used thereafter throughout treatment.

In experiment 1,11 mice were treated for 12 weeks with batch $(a)$ in a normal dose of $0.5 \mathrm{mg}$. One mouse died in the first week and one in the ninth. Batch $(a)$ was also used in experiment 2 but a higher dosage was attempted. However, unexpected deaths amongst the eight mice treated led to irregular schedules. Two mice out of three survived a course totalling $24 \mathrm{mg}$. in eight weeks, one of two mice survived $30 \mathrm{mg}$. in seven weeks, and one of three survived $36 \mathrm{mg}$. in seven weeks. The four survivors will be considered as a single group for which the mean normal dose was approximately $0.75 \mathrm{mg}$. and duration of treatment seven and a half weeks.

Batch $(b)$ was used in experiment 3 in a normal dose of $0.5 \mathrm{mg}$. Treatment was stopped after six and a half weeks owing to a death in the fifth week and two deaths during each of the sixth and seventh weeks. On the last day of the seventh week two more mice died when the five survivors were sacrificed and all seven mice examined for silicosis.

In experiment 4 , batch $(b)$ was used at two dose levels. One group was given a normal dose of $0.4 \mathrm{mg}$. and all 13 mice in it died by the eighth week. A second group of 12 mice was given a normal dose of $0.25 \mathrm{mg}$. There was a death after one week, another after six weeks and two more mice died after seven weeks. The last of these was examined together with the survivors, which were sacrificed two days later. A third group of five mice was left untreated for four weeks and then given a normal dose of $0.25 \mathrm{mg}$. for six weeks (experiment $4 \mathrm{c}$ ). None of this group died.

Aluminium Chelates.-Chelates of aluminium with oxytetracycline, sequestric acid, and dextran were prepared as described previously (Marks, 1959). The dextran (presented by Glaxo Laboratories Ltd.) was of the type used for restoring blood volume. In addition, Benger Laboratories Ltd. prepared for the present work a complex which contained $2 \cdot 3 \%$ aluminium and $37.4 \%$ dextran of low molecular weight, together with water and $\mathrm{NaCl}$. The latter dextran complex will be distinguished in the text by the letter $B$ and the former by $A$.

The Al-dextran complex A used in experiment 1 contained $0.011 \%$ aluminium. It was given to seven mice intravenously in a dose of $0.2 \mathrm{ml}$. twice in the first week and $0.4 \mathrm{ml}$. twice in each of the second and third weeks. Subsequently $0.5 \mathrm{ml}$. was given intraperitoneally three times a week for nine weeks. A single death occurred in the tenth week.

For experiment 2, dextran complex A was prepared to contain $0.022 \%$ aluminium. It was given intraperitoneally to nine mice three times weekly, the dose being increased from 0.15 to $0.5 \mathrm{ml}$. over a period of two weeks and maintained at $0.5 \mathrm{ml}$. for a further five weeks. There were single deaths after two, three, and five weeks, and two animals died after seven weeks. The four survivors were left untreated for the eighth and ninth weeks. The same course of the complex was given to three control mice, which suffered no loss.
The Al-dextran complex A used in experiment 3 contained $0.011 \%$ aluminium and was given by the intraperitoneal route three times weekly, achieving a dose of $0.5 \mathrm{ml}$. in the first week, which was maintained for six more weeks. Twelve mice were treated, one dying in the sixth and another in the seventh week. Owing to an accident, control mice given similar treatment were lost. A group of four mice which had received no silica were therefore treated later (experiment $4 \mathrm{~b}$ ) with the same dosage of complex A. These controls were treated for 10 weeks, a duration intermediate between that of experiment 1 and experiment 3. (A full complement of controls was not practicable for experiment 1.)

Al-dextran complex $\mathbf{B}$ was used in a concentration equivalent to $0.037 \%$ aluminium and in a normal dose of 0.25 or $0.5 \mathrm{ml}$. given intraperitoneally three times weekly. The lower dose was achieved in steps over one week, the higher over two weeks. In experiment 2, nine mice were treated without loss using the lower dose for 12 weeks except for a rest period in the eighth and ninth weeks. A second group of nine were given the higher dose but, after three deaths in seven weeks, treatment was suspended for two weeks and the survivors were then killed. Three control mice were treated at each dose level. A normal dose of $0.25 \mathrm{ml}$. was used in experiment 3 . The course was ended after seven weeks and the survivors killed following a death after three weeks and three deaths in the seventh week.

The complexes of aluminium with oxytetracycline and sequestric acid used in experiment 1 were prepared to contain $0.011 \%$ aluminium. Eleven mice were treated with the former and six with the latter. Both drugs were given intraperitoneally three times weekly in a dose of $0.2 \mathrm{ml}$. for the first week, $0.4 \mathrm{ml}$. for the next two weeks, and $0.5 \mathrm{ml}$. for the remaining nine weeks. An additional group of 11 mice (not reported in Table 1) were given the same dosage of the oxytetracycline complex intravenously but toxicity compelled a change to the intraperitoneal route after three weeks and discontinuance of treatment after two more weeks. There were three deaths and three more mice were killed because of skin lesions developing in the sacral and dorso-lumbar areas.

Phenazines.-Two compounds, B749 and B778, were chosen as the most active of a number provided by Dr. V. C. Barry for examination in vitro (Marks, 1959). These drugs were insoluble and suspensions were made in $10 \%$ dextran solution for intraperitoneal injection. In experiment 1 , a dose of $1.6 \mathrm{mg}$. of compound B749 was given to seven mice three times weekly for six weeks. Only a single further dose was given in the following six weeks owing to signs of toxicity. There were deaths in the fifth, sixth, eighth, and ninth weeks. In experiment $2,2.4 \mathrm{mg}$. of B749 was given once weekly for 12 weeks. Nine mice were treated, eight surviving. Compound B778 was used only in experiment 1 ; a dose of $1.6 \mathrm{mg}$. was given three times weekly for six weeks and, after two weeks' rest, for a further four weeks. One of the seven mice treated died in the seventh week.

Methylene Blue.-The dye was of the type supplied for vital staining. It was given intraperitoneally once daily for six days a week. Four groups, each of six mice, were 
treated, three groups being given a dose of $0.2 \mathrm{mg}$. daily for two, four, and eight weeks respectively, and the fourth group a dose of $0.1 \mathrm{mg}$. daily for eight weeks. Four mice from each group were sacrificed after eight weeks and two after 12 weeks. However, there were two premature deaths in the former section and one in the latter, all in the high dose groups.

Other Substances.-A number of drugs which appeared to protect phagocytes against the toxic effect of silica in vitro were tested in a single experiment which will not be described in detail. The drugs, with their normal daily dose given in parenthesis, were as follows:-Stilbamidine isethionate $(0.5 \mathrm{mg}$.), mepacrine methane sulphonate $(0.5 \mathrm{mg}$.), chloroquine sulphate $(0.5 \mathrm{mg}$.), promethazine hydrochloride $(0.5 \mathrm{mg}$.), and compound 3349 , a substituted methyl pyrimidine (1.0 mg.).
Readings

Examinations were confined to the liver. Approximately one-tenth of each was taken for histological examination. The following grades were used to classify the results, intermediate degrees being used in some instances:-

$$
\begin{aligned}
& \mathbf{O}=\text { no structural abnormality } \\
& \mathbf{A}=\text { a few small collections of mononuclear cells (not more than } \\
& \text { were found in some normal mice) } \\
& \mathbf{B}=\text { a small to moderate number of early silicotic nodules with } \\
& \text { little collagen production } \\
& \mathbf{C}=\text { a large number of well-developed silicotic nodules, which } \\
& \text { were predominantly cellular although collagen was obvious } \\
& \mathbf{D}=\text { intermediate between } \mathbf{C} \text { and } \mathbf{E} \text { in that some lesions were } \\
& \text { mainly cellular and others mainly collagenous } \\
& \mathbf{E}=\text { a large number of nodules in which collagen predominated } \\
& \mathbf{F}=\text { a large number of nodules, almost entirely acellular }
\end{aligned}
$$

\begin{tabular}{|c|c|c|c|c|c|}
\hline \multirow{2}{*}{$\begin{array}{l}\text { Experiment } \\
\text { No. and } \\
\text { Duration }\end{array}$} & \multirow{2}{*}{$\begin{array}{l}\text { Dose } \\
\text { of } \\
\text { Silica } \\
\text { (mg.) }\end{array}$} & \multirow[b]{2}{*}{ Treatment } & \multirow{2}{*}{$\begin{array}{c}\text { Initial } \\
\text { No. of } \\
\text { Mice } \\
\text { in Group }\end{array}$} & \multicolumn{2}{|c|}{ Examinations at End of Experiment } \\
\hline & & & & $\begin{array}{c}\text { Total Liver Collagen } \\
\text { (mg.) }\end{array}$ & $\begin{array}{l}\text { Histological Gradings } \\
\text { (see text) }\end{array}$ \\
\hline \multirow{5}{*}{ (12 weeks) } & $3 \cdot 5$ & & & $16 \cdot 0,15 \cdot 8,13 \cdot 3,10 \cdot 1,10 \cdot 0,9 \cdot 4$ & $\mathbf{E}, \mathbf{E}, \mathbf{C}+, \mathbf{C}, \mathbf{E}, \mathbf{C}, \mathbf{D}+, \mathbf{C}+$, \\
\hline & $3 \cdot 5$ & $\begin{array}{l}\text { Compound 46-107 (medium } \\
\text { dose) }\end{array}$ & 11 & $5 \cdot 7,4 \cdot 3,3 \cdot 9,3 \cdot 9,3 \cdot 8,3 \cdot 6,3 \cdot 3$ & $\mathbf{B}+, \mathbf{C}, \mathbf{B}, \mathbf{B}, \mathbf{A}+, \mathbf{B}, \mathbf{A}, \mathbf{B}, \mathbf{B}$ \\
\hline & $\begin{array}{l}3 \cdot 5 \\
3 \cdot 5\end{array}$ & $\begin{array}{l}\text { Al-dextran } \\
\text { Al-oxytetracycline }\end{array}$ & $\begin{array}{r}7 \\
11\end{array}$ & & $\begin{array}{l}\mathbf{D}+, \mathbf{C}, \mathbf{B}+, \mathbf{B}, \mathbf{C}, \mathbf{B} \\
\mathbf{D}, \mathbf{E}, \mathbf{D}, \mathbf{C}+, \mathbf{C}+, \mathbf{D}, \mathbf{C}+,\end{array}$ \\
\hline & $\begin{array}{l}3 \cdot 5 \\
3 \cdot 5 \\
3 \cdot 5 \\
\mathrm{Nil} \\
\mathrm{Nil}\end{array}$ & $\begin{array}{l}\text { Al-sequestric acid } \\
\text { Phenazine B749 ( } 6 \text { weeks only) } \\
\text { Phenazine B778 ( } 10 \text { weeks only) } \\
\text { Nil } \\
\text { Compound 46-107 (medium }\end{array}$ & $\begin{array}{l}7 \\
7 \\
7 \\
6 \\
3\end{array}$ & $\begin{array}{l}11 \cdot 0,9 \cdot 6,9 \cdot 3,9 \cdot 2,7 \cdot 9,6 \cdot 9 \\
6 \cdot 1,4 \cdot 4,4 \cdot 3 \\
11 \cdot 2,10 \cdot 1,9 \cdot 7,9 \cdot 6,8 \cdot 7,7 \cdot 2 \\
3 \cdot 3,3 \cdot 0,2 \cdot 7,2 \cdot 7,2 \cdot 3, \text { lost } \\
3 \cdot 3,3 \cdot 2,3 \cdot 0\end{array}$ & $\begin{array}{l}\mathbf{D}, \mathbf{C}+\mathbf{D}, \mathbf{D}, \mathbf{D}, \mathbf{D} \\
\mathbf{C}, \mathbf{B}, \mathbf{A}+ \\
\mathbf{E}, \mathbf{D}, \mathbf{D}, \mathbf{D}, \mathbf{D}, \mathbf{D} \\
\mathbf{O}, \mathbf{A}, \mathbf{A}, \mathbf{O}, \mathbf{O}, \mathbf{O} \\
\mathbf{A}, \mathbf{O}, \mathbf{O}\end{array}$ \\
\hline & Nil & Al-oxytetracycline & 6 & $3 \cdot 6,3 \cdot 2,3 \cdot 0,2 \cdot 8,2 \cdot 3$ & $\mathbf{O}, \mathbf{A}, \mathbf{A}, \mathbf{O}, \mathbf{O}$ \\
\hline \multirow[t]{2}{*}{$\begin{array}{c}2 \mathrm{a} \\
(9 \text { weeks) }\end{array}$} & $\begin{array}{l}3 \cdot 5 \\
3 \cdot 5 \\
3 \cdot 5 \\
3 \cdot 5\end{array}$ & $\begin{array}{l}\text { Nil } \\
\text { Compound 46-107 (high dose) } \\
\text { Al-dextran (high dose, } 7 \text { weeks) } \\
\text { Al-low molecular weight dextran } \\
\text { (high dose, } 7 \text { weeks) }\end{array}$ & $\begin{array}{l}8 \\
8 \\
9 \\
9\end{array}$ & $\begin{array}{l}12 \cdot 6,9 \cdot 2,8 \cdot 2,8 \cdot 1,7 \cdot 6,7 \cdot 0,6 \cdot 4 \\
3 \cdot 9,3 \cdot 2,3 \cdot 2,3 \cdot 1 \\
6 \cdot 9,5 \cdot 6,4 \cdot 7,4 \cdot 1 \\
11 \cdot 0,5 \cdot 1,4 \cdot 8,4 \cdot 8,3 \cdot 0, \text { lost }\end{array}$ & $\begin{array}{l}\mathbf{D}, \mathbf{C}+, \mathbf{D}, \mathbf{C}+, \mathbf{C}+, \mathbf{D}, \mathbf{C} \\
\mathbf{A}, \mathbf{B}, \mathbf{A}+, \mathbf{A}+ \\
\mathbf{C}, \mathbf{A}+, \mathbf{A}+, \mathbf{B}+ \\
\mathbf{D}, \mathbf{D}, \mathbf{C}+, \mathbf{C}+, \mathbf{C}+, \mathbf{D}\end{array}$ \\
\hline & $\begin{array}{l}\text { Nil } \\
\text { Nil }\end{array}$ & $\begin{array}{l}\text { Al-dextran (high dose) } \\
\text { Al-low molecular weight dextran } \\
\text { (high dose) }\end{array}$ & $\begin{array}{l}3 \\
3\end{array}$ & $\begin{array}{l}6 \cdot 1,4 \cdot 8,3 \cdot 8 \\
3 \cdot 9,3 \cdot 3, \text { lost }\end{array}$ & $\begin{array}{l}\mathbf{B}+, \mathbf{B}, \mathbf{A}+ \\
\mathbf{B}, \mathbf{B}, \mathbf{B}\end{array}$ \\
\hline \multirow{3}{*}{$\begin{array}{c}2 \mathrm{~b} \\
\text { (12 weeks) }\end{array}$} & $3 \cdot 5$ & & 8 & 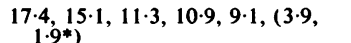 & $\mathrm{C}+, \mathrm{D}, \mathrm{E}, \mathrm{D}, \mathrm{D},(\mathrm{C}+, \mathrm{C})$ \\
\hline & $3 \cdot 5$ & $\begin{array}{l}\text { Al-low molecular weight dextran } \\
\text { (10 weeks only) }\end{array}$ & 9 & $108,10 \cdot 3,9 \cdot 8,9 \cdot 3,9 \cdot 2,8 \cdot 9,7 \cdot 0$ & $\mathbf{E}, \mathbf{D}, \mathbf{C}, \mathbf{C}, \mathbf{D}+, \mathbf{D}, \mathbf{D}+, \mathbf{C}+$, \\
\hline & $\begin{array}{l}3 \cdot 5 \\
\text { Nil }\end{array}$ & $\begin{array}{l}\text { Phenazine B749 (low dose) } \\
\text { Al-low molecular weight dextran } \\
\text { (10 weeks only) }\end{array}$ & $\begin{array}{l}9 \\
3\end{array}$ & $\begin{array}{l}5 \cdot 9,5 \cdot 2,5 \cdot 1,4 \cdot 9,4 \cdot 9,4 \cdot 0,4 \cdot 0,3 \cdot 9 \\
3 \cdot 8,3 \cdot 7,3 \cdot 6\end{array}$ & 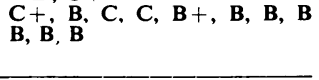 \\
\hline \multirow[t]{4}{*}{$\begin{array}{c}3 \\
\text { (7 weeks) }\end{array}$} & $3 \cdot 5$ & Nil & 20 & $\begin{array}{l}10 \cdot 3,9 \cdot 9,9 \cdot 8,9 \cdot 0,7 \cdot 6,7 \cdot 1,7 \cdot 0 \\
7 \cdot 0,6 \cdot 9,6 \cdot 4,5 \cdot 7,5 \cdot 7,5 \cdot 4,4 \cdot 9 \\
4 \cdot 7\end{array}$ & \\
\hline & $3 \cdot 5$ & $\begin{array}{l}\text { Compound 46-107 (medium } \\
\text { dose) }\end{array}$ & 12 & $4 \cdot 1,3 \cdot 8,3 \cdot 4,3 \cdot 3,3 \cdot 0,3 \cdot 0$, lost & \\
\hline & $3 \cdot 5$ & Al-dextran & 12 & $4 \cdot 6,4 \cdot 0,3 \cdot 9,3 \cdot 9,3 \cdot 8,3 \cdot 8,3 \cdot 7,3 \cdot 4$ & $\mathbf{B}, \mathbf{A}+, \mathbf{A}+, \mathbf{A}+, \mathbf{B}$, \\
\hline & $3 \cdot 5$ & Al-low molecular weight dextran & 11 & $9 \cdot 4,8 \cdot 4,6 \cdot 3,6 \cdot 1,5 \cdot 4,4 \cdot 9,4 \cdot 9$ & $\mathbf{C}+, \mathbf{D}, \mathbf{C}, \mathbf{C}+, \mathbf{C}, \mathbf{D}, \mathbf{C}$ \\
\hline $\begin{array}{c}4 a \\
\text { (7 weeks) }\end{array}$ & $\begin{array}{l}3 \cdot 5 \\
3 \cdot 5\end{array}$ & $\begin{array}{l}\text { Nil } \\
\text { Compound 46-107 (low dose) }\end{array}$ & $\begin{array}{r}7 \\
12\end{array}$ & $\begin{array}{l}9 \cdot 0,7 \cdot 1,6 \cdot 3,6 \cdot 2,5 \cdot 9,4 \cdot 6 \\
3 \cdot 9,3 \cdot 9,3 \cdot 6,3 \cdot 4,3 \cdot 2,2 \cdot 8,2 \cdot 8 \text {, } \\
2 \cdot 6,1 \cdot 9\end{array}$ & $\begin{array}{l}\mathbf{D}, \mathbf{C}+, \mathbf{D}, \mathbf{C}, \mathbf{C}+, \mathbf{D} \\
\mathbf{C}, \mathbf{B}+\mathbf{B}\end{array}$ \\
\hline $\begin{array}{c}4 b \\
(10 \text { weeks })\end{array}$ & Nil & Al-dextran & 4 & $3 \cdot 7,3 \cdot 4,3 \cdot 1,2 \cdot 7$ & $\mathbf{A}+, \mathbf{A}+, \mathbf{A}+, \mathbf{A}+$ \\
\hline $\begin{array}{c}5 \mathrm{~b} \dagger \\
(12 \text { weeks })\end{array}$ & $\begin{array}{l}5 \\
5 \\
5 \\
\text { Nil }\end{array}$ & $\begin{array}{l}\text { Nil } \\
\text { Methylene blue ( } 2 \text { weeks only) } \\
\text { Methylene blue ( } 4 \text { or } 8 \text { weeks } \\
\text { only) } \\
\text { Nil }\end{array}$ & $\begin{array}{l}4 \\
2 \\
6 \\
4\end{array}$ & $\begin{array}{l}7 \cdot 4,6 \cdot 1,5 \cdot 7,3 \cdot 4 \\
5 \cdot 0,2 \cdot 4 \\
2 \cdot 8,2 \cdot 7,2 \cdot 6,2 \cdot 5,2 \cdot 3 \\
2 \cdot 6,2 \cdot 3,2 \cdot 2,1 \cdot 9\end{array}$ & $\begin{array}{l}\mathbf{D}+, \mathbf{D}, \mathbf{D}+, \mathbf{B} \\
\mathbf{C}, \mathbf{O}, \mathbf{A}, \mathbf{B}, \mathbf{O} \\
\mathbf{A}, \mathbf{O}, \mathbf{O}, \mathbf{O}\end{array}$ \\
\hline
\end{tabular}

Collagen was estimated in the remainder of the liver by the method of Stacy and King (1954). The values

TABLE 1

DRUG TREATMENT OF EXPERIMENTAL SILICOSIS IN MICE

*These two values are attributed to a technical fault.

tSee text for an account of $5 a$. 
presented in Table 1 are corrected for the portion of liver taken for histology and are given in the same order as the histological gradings.

\section{Results}

Compound 46-107.-With the higher dosages deaths became frequent after several weeks' treatment. More occurred with batch (b) than with (a) but, as the two samples were not used simultaneously, variation in the susceptibility of the mice cannot be excluded. Details of the mortality are given above. The drug afforded a considerable degree of protection against the development of silicosis in experiments, $1,2 \mathrm{a}$, and 3. Protection was less but still obvious in experiment $4 \mathrm{a}$ where the dose was reduced to $0.25 \mathrm{mg}$. daily.

The result of experiment $4 c$, in which treatment was started four weeks after the silica injection, has been omitted from Table 1 because of certain special histological features. The controls given silica but left untreated had liver collagen values of $10.6,9.4$, $9 \cdot 2,7 \cdot 1$, and $6.6 \mathrm{mg}$., and histological gradings of $\mathrm{D}+, \mathrm{D}+, \mathrm{D}, \mathrm{E}$, and $\mathrm{D}$ respectively. The mice receiving delayed treatment had collagen values of $5 \cdot 6,5 \cdot 3,4 \cdot 1$, and $4 \cdot 1 \mathrm{mg}$., the fifth estimation being lost. Histologically, the livers of this group of treated mice were difficult to classify in the grades used for the other experiments. Their lesions tended to be stellate and were less cellular than in the untreated mice, giving the impression that although existing damage had not been repaired, progression of the disease had been halted or slowed. It should be noted that a dose of only $0.25 \mathrm{mg}$. was used in this experiment.

Statistical analysis of the liver collagen values for mice given silica and subsequently treated with compound 46-107 shows them to have been significantly lower than the values for untreated silicotic mice. The level of significance was $P<0.01$ in each of the five experiments $1,2 \mathrm{a}, 3,4 \mathrm{a}$, and $4 \mathrm{c}$.

Aluminium Chelates.-The complex of aluminium with ordinary dextran (molecular weight 150,000 ) clearly protected mice against silicosis but not as well as 46-107. A dose equivalent to $55 \mu \mathrm{g}$. aluminium (three times weekly intraperitoneally) was well tolerated but double this amount proved toxic. In the livers of both normal and silicotic mice treated with either dose small aggregations of cells were seen with abundant rather hyaline cytoplasm which were associated with a minor degree of collagen production. These cells, which were assumed to be altered macrophages or reticulo-endothelial cells, were not seen in mice that received dextran in association with phenazine compounds.

The complex with dextran of low molecular weight had very little protective action. It induced liver changes similar to those described immediately above. The oxytetracycline and sequestric acid chelates of aluminium had no protective action.

Statistical analysis of the liver collagen values in mice given silica and treated with aluminium complexes and those left untreated gives the following levels of significance for the differences observed:-

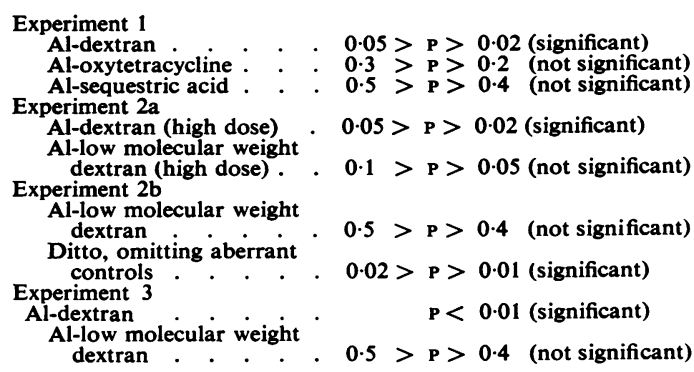

Phenazines.-A considerable degree of protection against the development of silicosis was afforded by the phenazine compound B749 in both experiments 1 and $2 b$. However, the dose chosen for the first experiment was too high and four of the seven treated mice died. Phenazine compound B778 was well tolerated but not protective.

The levels of significance for collagen values in the phenazine experiments are as follows:-

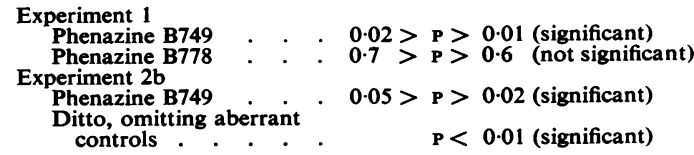

Methylene Blue.-The dust suspension used in experiment 5 was unsatisfactory and the degree of silicosis in the untreated mice killed at eight weeks was too low for useful comparisons to be made. However, in the second part of the experiment, terminated four weeks later, the results did allow the effect of treatment to be assessed. As the number of mice observed for 12 weeks was small, those which received the higher dose of dye for four and eight weeks and the lower dose for eight weeks have been grouped together. A considerable degree of protection by the dye was evident in this group, the liver collagen values being significantly lower than in the untreated mice $(P<0.01)$.

Other Drugs.-The experiment to determine the protective effects of stilbamidine, mepacrine, chloroquine, promethazine, and compound 3349 was technically satisfactory but no inhibitory action on the development of silicosis was demonstrated histologically. Collagen estimations were therefore omitted and the results will not be reported in detail. 


\section{Discussion}

In evaluating the antagonists to silica, which were the subject of the present investigation, account must be taken of the relatively large dose of highly fibrogenic dust (tridymite) against which protection was sought. None of the drugs studied gave complete protection but several gave results which indicated that the drug treatment of silicosis in man is a reasonable target.

Experiments in vitro suggested that compound 46-107, although somewhat more toxic to isolated cells, was a more potent antagonist to silica than compound $48-80$, the first of the series to be examined. It was therefore disappointing in the present investigation to find that the dose of 46-107 had to be raised to a toxic level to achieve results comparable with those reported for 48-80. Although 46-107 lacks the disruptive effect of 48-80 on mast cells (Norton, 1958), it was not possible to treat mice with a dose very much larger than that previously used for 48-80 (Marks, et al., 1958). However, it now appears possible that toxicity to mast cells and protection against silica may be dissociated in this group of drugs, encouraging the hope that effective but less toxic derivatives may be found.

In previous experimental work and in clinical practice, aluminium has been used in a relatively insoluble form. The soluble preparations of aluminium described in the present work were devised to see whether systemic treatment was practicable and effective. There was little difference in vitro between the protective activities of the chelates with oxytetracycline, sequestric acid, or normal dextran (Marks, 1959), and it is not clear why the first two were ineffective in mice. The chelate with dextran of low molecular weight had little activity either in vitro or in vivo. As both types of dextran chelate produced small lesions in the livers of normal mice, the use of such soluble aluminium complexes must be considered to carry a hazard until their effect in other species has been studied. There may be circumstances, however, such as in the treatment of silico-tuberculosis, in which side-effects might be risked for a temporary abatement of the silicotic element while the infective process is treated.

Phenazines have been studied and found effective by Barry and Conalty (1958) in connexion with the chemotherapy of experimental tuberculosis. Several of the group have been found to protect phagocytes against the effect of silica in vitro, although there was doubt as to the specificity of their action (Marks, 1959). Compounds B749 and B778 were both particularly active in vitro but in the present study only the former protected mice against the effects of silica. The difference appears to have been due to a lack of diffusibility in the case of B778, which may also account for its low toxicity. It would be premature to discuss the potentialities of compound B749 but a drug which may protect against both silica and tubercle bacilli is of obvious interest.

The use of methylene blue as an antagonist to silica was suggested by an earlier observation that it flocculates with polysilicic acid (James and Marks, 1956). As the dye is highly toxic for isolated macrophages, tests in vitro were unsatisfactory. Protection in vivo was clearly seen in the single experiment made on mice but circumstances have prevented the institution of the further animal tests which are obviously desirable.

It must be admitted that the dosage of the protective drugs described has been pushed to the point of toxicity in order to demonstrate unequivocal evidence of their activity. It is therefore highly probable that if less silica had been administered, more tolerable drug régimes could have been used with benefit. However, since the relative toxicity and protective power of a drug in one species may well be quite different in another, studies on mice such as the present one can claim to do no more than indicate lines of research of potential value.

We are indebted to Dr. V. C. Barry, the Wellcome Research Laboratories, New York, Benger Laboratories Ltd., and Glaxo Laboratories Ltd., for gifts of drugs acknowledged in the text, and to the Medical Research Council for a grant for apparatus. Our thanks are due also to Mr. C. A. Lediard for preparing the histological material, to Dr. G. Nagelschmidt for providing silica dusts, and to Dr. E. Lewis-Faning for the statistical analyses.

\section{REFERENCES}

Barry, V. C., and Conalty, M. L. (1958). Amer. Rev. Tuberc., 78, 62. Dworski, M. (1955). A.M.A. Arch. industr. Hith, 12, 229.

Englebrecht, F. M., Yoganathan, M., King, E. J., and Nagelschmidt, G. (1958). Ibid., 17, 287 .

James, Dinah, M., and Marks, J. (1956). J. Hyg. (Lond.), 54, 342. Kennedy, M. C. S. (1956). Brit. J. industr. Med., 13, 85.

Marks, J. (1959). Ibid., 16, 166.

Tames, Dinah M., and Morris, T. G. (1958). Ibid., 15, 1.

Stacy, B. D., and King, E. J. (1954). Brit. J. industr. Med., 11, 192. 